\title{
CATHOLICISM AND NATIONALISM IN THE VIEWS OF THE YOUNGER GENERATION OF LITHUANIAN CLERGY IN THE LATE-NINETEENTH AND EARLY- TWENTIETH CENTURIES
}

\section{VILMA ŽALTAUSKAITÉ}

ABSTRACT. In historical scholarship the attitudes of the clergy at the turn of the century are often referred to as a generational conflict between older and younger clergymen. In this paper an attempt is made to establish the basis of the conflict and the extent to which it depended on the differences in age and outlook - in the different interpretations of the ratio between nationalism and Catholicism. The analysis of Catholic texts suggests that the ideological differentiation of the clergy can only partly be accounted for by the generation gap. The confrontation'the young versus the old' was conditioned by different conceptions of the clergy's duties and the relationship between Catholicism and nationalism rather than by the conflict of their age groups. Clergymen treating Lithuanian national movement positively advocated the synthesis of Catholicism and (Lithuanian) nationalism, while others considered Catholicism as a universal dimension and supported the idea of political Lithuanian-Polish union against Lithuanian modern nationalism.

The attitude of the Catholic clergy towards the Lithuanian national movement in the second half and at the turn of the nineteenth century is not a neglected problem. ${ }^{1}$ Therefore this study focuses only on the

${ }^{1}$ Both the process of the national movement and the place of the clergy in it have been investigated in many works: Michał Römer, Litwa. Studyum o odrodzeniu narodu Litewskiego (Lwów, 1908, pp. 190-221, 309-316; Rimantas Vèbra, Lietuvos katalikudvasininkija ir visuomeninis judejjimas (Vilnius, 1968); Edvardas Vidmantas, Kataliku Bažnyčia ir nacionalinis klausimas Lietuvoje XIX a. antrojoje pusejje-XXa. pradžioje (Vilnius, 1987); Lietuviu Atgimimo Istorijos Studijos (henceforth LAIS)(Vilnius 1994), t. 7 Atgimimas ir Kataliku Bažnyčia; Egidijus Aleksandravičius, Antanas Kulakauskas, Caru valdžioje. Lietuva XIX anžiuje (Vilnius, 1996); Miroslav Hroch, 'Social and Territorial Characteristics in the Composition of the Leading Groups of National Movements', Andreas Kappeler (ed.), Comparative Studies on 
process of the positive self-determination of the clergy with respect to that movement, i. e., the determination of the clergyman of Lithuania to be a Lithuanian clergyman. (Lithuanian) nationalism is to be associated with the concept of a modern nation, defined by the dimensions of territory, culture and citizenship. This conception is qualitatively different, it acknowledges the equality of every individual of that collective community. ${ }^{2}$ The previous concept of the nation was characterized by the traditional perception of nationalism (in the upper social strata). In the context of Lithuania it meant the idea of the continuity of the former united Lithuanian-Polish state. In the late nineteenth century the ideological differentiation of Lithuanian society was influenced by the tension between the two co-existing ideas Lithuanian modern nationalism and the historical Lithuania in union with Poland.

Lithuanian nationalism complicated the self-determination of the clergy, as a social group per se committed to the Church. The clergy could reject the challenge of modern nationalism, but by doing so it risked losing its influence on society. Looking for an answer, the clergy had to acknowledge the definition of the nation as a combination of traits, among which religion was only one of the components of nationalism. In that way it could ensure a dominating (or at least, stable) place in that scale of values for itself. Thus the two different attitudes towards nationalism - its rejection or attempts to adapt it led to a split in the clergy. They were faced with a choice between historical statehood, based on the idea of the Lithuanian-Polish union, and Lithuanian modern nationalism intent on integrating society on an ethnolinguistic basis.

In historical scholarship the opposition of this type is often referred to as the generation gap. The leaders of the Lithuanian national revival and their adherents are associated with the young clergymen, while their opponents with the old. This treatment is also found

Governments and Non-dominant Ethnic Groups in Europe, 1850-1940 (1996), The Formation of National Élites, pp. 257-275; Pranas Vaičekonis, Kataliku dvasininkijos juridine padetis XIX a. Lietuvoje (Vilnius, 1999), et al. On the attitudes of other clergymen, see Aleksandras Merkelis, Juozas Tumas Vaižgantas, 3rd ed. (Vilnius, 1989); Antanas Alekna, Žemaičiu vyskupas Motiejus Valančius, 2nd ed. (Chicago, 1975); Aldona Vaitiekūnienè, Vaižgantas (Vilnius, 1982); Vanda Zaborskaitè, Maironis (Vilnius, 1987); Regina Mikšytè, Antanas Baranauskas (Vilnius, 1993); LAIS, t. 8, Asmuo tarp tautos ir valstybes; Vytautas Merkys, Vyskupas Motiejus Valančius. Tarp katalikiškojo universalizmo ir tautiškumo (Vilnius, 1999), et al.

${ }^{2}$ Anthony D. Smith, Nationalism. A Trend Report and Bibliography, Current Sociology, vol. XXI, no. 3 (1973), p. 18. 
in contemporary texts, in official documents and present-day publications. $^{3}$

The purpose of the present study is to determine to what degree the aforementioned processes enable the analysis on the basis of a particular generation category and whether it can be used as a tool to reveal the ideological divide in the clergy, its preconditions, its real content and expression. And lastly - how realistic such division is, to what extent the conflict was conditioned by the age differences and by the ideological confrontation, different interpretations of the combination of nationalism and Catholicism.

The sources of the study are illegal ${ }^{4}$ Lithuanian Catholic periodical publications - Žemaičiu ir Lietuvos Apžvalga (hereafter Apžvalga), issued between 1889 and 1896, Tèvynès Sargas (hereafter Sargas), 1896-1904, Žinyčia, 1900-1902, and other works of Catholic authors.

The concept 'generation' entered scholarship together with the rise of sociology in the latter half of the nineteenth century. It was also a result of the formation of modern society and of the change of the concept of the individual in time. ${ }^{5}$ In Lithuanian historiography the term was more widely used in relation to the history of literature and arts. ${ }^{6}$ In historical scholarship the term was used more journalistically or formally, without any attempt (and possibly seeing no need) to define its precise meaning. An article by Juozas Eretas is worth noting, in which the author distinguished the generations according to the periods of the intensity of their activity, however, without structuring them according to the tensions within the generation. ${ }^{7}$ In his study

${ }^{3}$ [?], 'Truputis skaitlių isz Žemaiczių Vyskupijos', Tèvynès Sargas, no. 1 (1900), p. 66; Römer, Litwa, pp. 117-120; J. Tumas, 'Apžvalga' ir apžvalgininkai (Kaunas, 1925), p. 7-9; Vèbra, Lietuvos dvasininkija, p. 170-171; Aldona Gaigalaitè, Klerikalizmas Lietuvoje (Vilnius, 1970), p. 20-24; E. Vidmantas, 'Inteligentijos vaidmuo. Jos idèjinè diferenciacija', Lietuviu nacionalinio išsivadavimo judejjimas ligi 1904 metu (Vilnius, 1987), p. 167-171; Aleksandravičius and Kulakauskas, Caru valdžioje, pp. 191-192, 489.

${ }^{4}$ In the period between 1864 and 1904 the publication of Lithuanian books in the Latin alphabet was banned by Russian rule. Nevertheless, the publication of Lithuanian books continued illegally, mostly in Prussia.

${ }^{5}$ Annie Kriegel, 'Generational Difference: The History of an Idea', Daedalus, Fall (1978), p. 24.

${ }^{6}$ Faustas Kirša, 'Trys rašytojų kartos', Vairas (1929), no, 1, pp. 74-82; no. 2, pp. 152-159; J. Radžvilas, 'Dèl literatūrinių kartų ir generacijų', Kultūra, no. 2 (1930), pp. 115-120; Giedrius Viliūnas, Literatūrinis gyvenimas nepriklausomoje Lietuvoje (1918-1940) (Vilnius, 1998), p. 23.

7 Juozas Eretas, 'Dvi generacijos mūsų krikščioniškos kultūros tarnyboje', Lietuviu Kataliku Mokslo Akademija, Suvažiavimo darbai, t. 7 (Roma, 1972), pp. 3-54. 
'Epochų signatūros' (Signatures of the Epochs), Vytautas Kavolis discusses a specific form of generational conflict - the "parents versus children' conflict as a factor of the cultural change. ${ }^{8}$ A number of Polish historians analyzed the importance of sociocultural and political factors for the formation of generation consciousness. ${ }^{9}$

In this paper we shall adhere to the historico-cultural concept of the generation. The generation is a group of people tied by common value orientations, resulting from shared experience (or past), and by common historical circumstances and socio-cultural situation. Their collective behaviour manifests itself by their peculiar adaptation and transmission of cultural information. The acknowledged change of the generation is every ten to fifteen years. However, this aspect is not essential in the definition - the most important is the socio-cultural context, in which the individuals, born in a particular period, live and act. From the point of view of sociology, they create their collective biography. Such a conception of the generation is not generalized, since common experience does not necessarily presuppose identical reactions. Therefore, it is possible to speak not about a generation in corpore or about the generation used in the sociological sense as about a particular type of social location ${ }^{10}$, but only about a part of the generation $^{11}$ - in our case, about the pro-Lithuanian clergy, which expressed its attitudes in the above-mentioned illegal Catholic press. The starting point of this study is the year 1861 - the abolition of serfdom, which not only made the peasant a subject of civil law, ${ }^{12}$ but also conditioned the formation of a new, free and consequently more self-reliant person ${ }^{13}$ and at the same time increased the number of socially active individuals in society. The year 1863 - the uprising and its suppression - is also important in the sense of the direction of democratization. Its result was the appearance of Aušra, produced in 1883 by the Lithuanian-speaking intellectuals. This publication was a declaration of modern Lithuania, proclaimed in addition to the still existing

${ }^{8}$ V. Kavolis, Žmogus istorijoje (Vilnius, 1994), pp. 464-470.

${ }^{9}$ Ludwik Hass, 'Pokolenia inteligencji Królestwa Polskiego', Przeglad Historyczny, t. LXV, z. 2 (1974), pp. 286-316; Bohdan Cywiński, 'Doświadezenie sześciu pokoleń', Znak, nr. 292-293 (1978), pp. 1278-1331; B. Cywiński, Rodowody niepokornych, 2nd ed. (Warszawa, 1996); Roman Wapiński, 'The Problem of Generations in 19th and 20th Century', Acta Poloniae Historica, 78 (1998), pp. 135-160.

${ }^{10}$ In greater detail, see Karl Mannheim, Essays on the Sociology of Knowledge (London, 1964), p. 291-310.

${ }^{11}$ Ibid., p. 304.

${ }^{12}$ Aleksandravičius and Kulakauskas, Caru valdžioje, p. 214.

${ }^{13}$ Kavolis, Žmogus, p. 450. 
idea of historical Lithuania, associated with Poland in a union. Thus the chronological boundaries of the generations would be: 1860 (1861, $1863-1864)-1875-1890-1905 .{ }^{14}$ As we are adhering to the historicocultural conception of the generation, the 'step' of its change would be about 15 years, marking the approximate age when the individual starts a conscious critical dialogue with his/her sociocultural milieu. ${ }^{15}$

The place of nationalism in the value system of the clergy can be determined only after the discussion of the official attitude of the Catholic Church - the institution, forming the ecclesiastical doctrine, in this case in relation to modern nationalism. Due to the attempts of the modern states to subordinate religion to the state, the conflict between the state and the Catholic Church increased in the second half of the nineteenth century. ${ }^{16}$ The process of Italy's unification in the mid-nineteenth century clearly demonstrated the 'nationalistic' dangers for the Church, i.e., its loss of the economic and political power. The position of the Catholic Church developed in the direction of social thought rather than nationalism. The last two decades of the nineteenth century were a period of change in the Church, which to a great extent was conditioned and protected by the policy of Pope Leo XIII. He obviously endeavoured to establish diplomatic contacts with the so-called non-Catholic countries (including Russia), in which the tension between the state and the church was complicated by the collision of confessions. Leo XIII sought to preserve the Church united, even at the expense of concessions to Russia in order to influence it at least minimally. Against the background of such aims of the Pope, the Polish political aspirations for statehood, provoking the sanctions of the authorities against the Church as well, complicated the relations between the Vatican and Russia and were undesirable. Besides, the state was not the exceptional subject of the teaching of the Church. According to the Pope, both the state and the nation did not contradict natural law (given by God), and it was the law acknowledged by the Church. The nation, however, takes precedence over the state. The nation, created by love, can exist without a state - the institutional juridical society. ${ }^{17}$ True, the relationship between the nation and the

${ }^{14}$ Therefore the names of the persons mentioned in the text will be accompanied by the dates of their birth.

${ }^{15}$ In the biological conception of the generation this change takes place every 30 years.

${ }^{16}$ Chadwick Owen, The Secularization of European Mind in the Nineteenth Century (Cambridge, 1975), pp. 130-131

${ }^{17}$ Stanisław Jarocki, Katolicka nauka spoleczna (Paris, 1964), pp. 386-387.

A Christian structure of the state is discussed in the papal encyclical 'Immortale Dei', issued on 1 Nov. 1885. 
state is not impossible and negative. According to Thomas Aquinas, the tie between nation and state can ensure the citizens' welfare (bonum commune) - the ideal of the Christian state. Therefore 'weak' nations, whose states cannot afford to undertake their welfare provision, can be taken under the aegis of stronger ones. ${ }^{18}$ That kind of teaching was not an endorsement of modern national aspirations, and it also complicated the participation of the clergy in national movements. That trend in Church teaching is found in the 19 March 1894 encyclical 'Caritatis', addressed to the bishops of the Polish nation rather than to those of the state. The address to the Polish bishops in Austria contains advice on how the Poles should deal with the Ukrainian Uniates (as a consequence of the tolerant Austrian state policy the contemporary Galicia had developed into a 'Ukrainian Piemonte' - a centre of national movement). There the national aspirations of the Ukrainians clashed with those of the Poles, though the same faith was considered the main tie binding the two nations - 'treat them as brethren', 'let your hearts and desires be united'. ${ }^{19}$ As in the appeal to the bishops under Russian rule national issues were not dealt with, it can be surmised that the attitude to the Lithuanian national movement must have been similar. The official Church was interested not in separating factors (nationality), but in those things which unite - the Catholic faith as the basis and essence of the universality of the Church. However, in the late nineteenth century the universality of the Church was not sufficient in order to overcome the nationalist aspirations. Even vice versa nationalism dictated the behaviourist model of the Church. True, that affected the clergy and the believers in their concrete sociopolitical activities rather than the higher dignitaries.

In the late nineteenth century the Catholic Church of Lithuania underwent changes based on ethnic separation - processes that were conditioned by the tensions between the Lithuanian and the Polish nationalisms and escalated by the integrational attempts of the latter. The different responses of Polish and Lithuanian societies to the aforementioned encyclical display the difference in the attitudes and ideals and their polarization. Similar processes were taking place in the sphere of the clergy, and they partially reflected the different

${ }^{18}$ Jarocki, Katolicka nauka, p. 388.

19 Komentarz do Encykliki Leona XIII przez Stanisława Tarnowskiego, Lietuvos nacionalinė Martyno Mažvydo biblioteka, Rankraščił skyrius (hereafter LNMMB RS), f. 130, b. 2418, 1. 22. The author of the commentary was a professor of the University of Cracow. His unionist tendencies are evident in his memoirs about the journey in Lithuania after 1878; see S. Tarnowski, $Z$ wakacji, t. 1, wyd. drugie (Kraków, 1894), s. 277-434. 
viewpoints of the so-called younger and older clergy. The encyclical's conception of a single united Poland had to be acceptable to that part of the clergy which supported the unionistic tradition of the PolishLithuanian state. ${ }^{20}$ Commenting on the encyclical and its address to the Polish bishops, Tarnowski asked:

What does that mean? That the Pope understands the situation and interprets relations as they are... But he also understands that in the partition the nation survived, he understands the fact that the nation is one and the same though existing in different states and relations. It is the understanding of the person who bases himself on natural law and who understands that the partition of the state did not destroy the nation's life and the fact of unity, neither could it destroy its natural right to live and to exist. ${ }^{21}$

The young who rallied round the Lithuanian Catholic periodical publication Apžvalga (Review), tended not to notice the encyclical. True, that was not due to the title, but because that encyclical, requiring obedience to authority, obstructed the implementation of the Apžvalga programme - the defence of Catholicism and Lithuanianness against Orthodoxy. Apžvalga did not question the principle that 'all power comes from God' and everybody must be obedient to and honour it. ${ }^{22}$ Nevertheless, it considered that in Lithuania that statement would be literally understood just in that manner both by all the believers and the clergy and therefore protested against its publication in Lithuanian. 'We believe that in Lithuania the arguments of the encyclical would be understood quite differently than they should be ${ }^{23}$ and examples were presented attesting the exaggerated esteem for the authorities on the part of the clergy due the latter's weakness and fear. ${ }^{24}$ Apžvalga's attitude to the encyclical demonstrated that it was not treated as a document regulating its activity, still less did it exert on it the influence,

${ }^{20} \mathrm{~S}$. Tarnowski, Nasze dzieje w ostatnich stu latach, wyd. drugie (Kraków, 1896), p. 189.

${ }^{21}$ Komentarz do Encykliki, 1. 17.

${ }^{22}$ Apžvalga expressed its sympathy to that principle informing about the appearance of the Lithuanian translation of the encyclical (which probably was not done on Apžvalga's initiative), adding, nevertheless, that it is not only unto the government that its things are to be rendered, but it also behoves its government to render unto its subjects their things, i.e., their freedom. On this point, see F. M. [?], 'Szvento Tèvo popiežiaus Leono XIII. Encyklika arba gromata visiems Lenku arcivyskupams ir vyskupams 1894 metuose', Apžvalga, nr. 15 (1894), p. 117.

${ }^{23}$ Editorial comment and supplement, Apžvalga, nr. 23 (1894), p. 181.

${ }^{24}$ Ibid., p. 180-181. 
ascribed to it by Vidmantas - in his opinion, the encyclical allegedly strengthened the positive attitude of the clergy to the tsarist autocracy. ${ }^{25}$ More attention was paid to the encyclical in the secular press after a commentary on it was published in Varpas,${ }^{26}$ which characterized its submissive tone and call to obey the government as a betrayal of the blood spilled in Kražiai. ${ }^{27}$ Apžvalga retorted: 'it is a lie', since the encyclical not only called on the faithful to be submissive to the government, but also to defend faith by offering passive resistance and taking a position of conscience in spite of the requirements of the authorities. ${ }^{28}$ Respectively, the encyclical did not condemn the guardians of the church in Kražiai, because they defended the faith. Thus, the attitude of Apžvalga to the encyclical did not so much display the relation with Polishness, but its own stance - to take care of and defend the faith by the believers themselves. ${ }^{29}$ It also showed that it rejected weakness, fear, and passiveness. In Apžvalga the encyclical did not become a means of escalating the Polish-Lithuanian conflict. In 1894 such a position, however, was an exception rather than the rule. At that time the rule was the unconditional defence of the rights of the Lithuanian language in the Church and the critique of the pro-Polish oriented clergy. At the initial stage, however, the latter issue was not Apžvalga's main aim, and it intended at least to remain neutral on that point. The aim was to defend Catholicism from Orthodoxy. Quite probably such a reaction from Polish society - to be labelled 'madmen, Litvomaniacs' - was also unexpected..$^{30}$ The concept was

${ }^{25}$ Vidmantas, 'Katalikų bažnyčia', p. 47.

${ }^{26}$ M. Joniškis [?], 'Švento Tèvo enciklika', Varpas, nr. 10 (1894), p. 146. It must be noted that the first comments in the Varpas were less categorical, the Apžvalga received even some appreciation. Cf. 'Tèvynés varpai', Varpas, nr. 7 (1894), p. 99-100; 'Lietuviški laikraščiai', Ibid., nsr. 8, pp. 124-125.

${ }^{27}$ In 1893, when the tsarist authorities attempted to close the church of the Benedictine nunnery in the small Žemaitijan town of Kražiai, the local people showed resistance. Armed Cossacks, sent by the authorities, attacked the believers defending the church, and among the latter there were casualties and wounded. The resistance was brutally crushed. In the trial, which took place the following year, every arrested defender was found guilty. The events in Kražiai became widely known through illegal Lithuanian publications and even foreign newspapers.

${ }^{28}$ N. [?], 'Kritika enciklikos Leono XIII, Apžvalga, nr. 24 (1894), p. 189.

${ }^{29}$ F. M. [?], Apžvalga, nr. 15 (1894), p. 117.

${ }^{30}$ The term 'Litvomaniac' to describe the lay leaders of the Lithuanian national movement came into use in the first half of the 1880s. It expressed the reaction of the Polish-oriented society to the Lithuanian national aspirations. Later this concept was also applied in respect to the clergy. In Lithuanian Catholic publications it was 
not new in the $1890 \mathrm{~s}$, and, nevertheless, it was used more in respect to the laymen. In this paper 'Litvomaniac' will be used to denote an individual, positively viewing the Lithuanian national movement. It would not be a mechanical transfer and usage of the then concept, rather it is laconic expression of the national attitude of an individual.

The initial neutrality of Apžvalga was conditioned by the circumstances of its appearance. The idea to publish a newspaper was initiated and realized by the seminarians of the Theological Seminary of Kaunas, members of a clandestine society, many of whom became active contributors to the paper. Thus the publication reflected the attitudes formed and fostered at the Seminary. In the beginning the Apžvalga represented the synthesis of the viewpoints of the professors and students, which was attested by the co-operation of the representatives of the older generation in Apžvalga.

The attitudes, which the older generation aimed to instill in the younger clergy, can be perceived from the text Paskutinis pamokslas vieno žemaičiu kunigo priěs smertį ${ }^{31}$ (The Last Sermon of a Žemaitijan Priest before his Death), which circulated in society during the years of the publication of Apžvalga. Financed by Bishop Mečislovas Paliulionis of Žemaitija, it ran into four editions (1889, 1895,1899 and 1905). ${ }^{32}$ The Bishop (b. 1834) was not a supporter of Lithuanian national aspirations. The text of the sermon defended the historical Polish-Lithuanian contacts, idealized the relations between the two states after the unions, ${ }^{33}$ acknowledged the parallel functioning of the Polish language in Lithuania ${ }^{34}$ and merely apprehended the threat of Orthodoxy. ${ }^{35}$ It could be stated that Lithuanian also performed a definite function in the text - it was used, since that was required by its direct addressee - the people. The author of the Last Sermon did not question the legality of the government. All occurrences depend on God; the foreign (i.e., non-Catholic) rule had been sent by God as

sometimes used in inverted commas, thus stressing its alien character, and it was also employed consciously to characterize one's own activity. The acceptance of the term in the latter sense, i.e., their own identification with the laity, accused of the 'mania,' possibly shows the objective similarity of the Catholic trends and of the interests of the laity. The term 'Polonomaniac' originated as an antipode to 'Litvomaniac.'

${ }^{31}$ Old spelling conventions are replaced by those of Modern Lithuanian.

${ }^{32}$ Mikšytè, Antanas Baranauskas, pp. 233-234.

${ }_{33}^{3}$ [Anon.] Paskutinis pamokslas wiena zemajczu kuniga priesz smerti (n.p., 1899), p. 10.

\footnotetext{
${ }^{34}$ Ibid., p. 56.

${ }^{35}$ Ibid., p. 19.
} 
a punishment for the sins. ${ }^{36}$ Consequently, repenting and redeeming the sins, the question will work itself out - the Catholic rule will return. True, which rule-Polish or Lithuanian - it will be is not discussed, the more so that any rule is transient. The essence is faith and repentance rather than nationality.

Similar considerations are found in the article of Seminary Professor Antanas Baranauskas (b. 1835). ${ }^{37} \mathrm{He}$ argued that God united Lithuania and Poland, therefore Lithuania will be reborn if such be the will of God. ${ }^{38}$ The similarity of the ideas and the logic of the discourse in the two texts leads to the conclusion that the discussion concerning the authorship of the Last Sermon is not yet finished, and the authorship of Baranauskas cannot yet be discarded entirely. ${ }^{39}$

The above-mentioned texts offer a model of an ideal clergyman. Faith, repentance and the search of the way to heavenly salvation makes up the essence of the clergyman's activity. Transient matters, and the more so any 'struggle', do not concern any clergyman. That type of attitude did not quite conform with the appeal of Leo XIII for the clergy to leave the walls of the sacristy; however with regard to Russia's policy on the Catholic Church a stipulation was made: to strive towards maintaining the status quo.

In 1890 Apžvalga carried an article entitled 'Genuine love of the homeland'. ${ }^{40}$ Its co-author was the inspector of the Theological Seminary of Kaunas, Eduardas Barauskas (b. 1836). ${ }^{41}$ In the words of Tumas (b. 1869), he was a 'representative of the old school', ${ }^{42}$ a 'Polish patriot', ${ }^{43}$ and, being an adherent of the unionist cultural tradition, he did not approve of the Lithuanian activities of the seminarians. ${ }^{44}$ Despite that attitude and pretensions to the monopoly of truth (the indication of the 'true' love of one's homeland) Barauskas's ideas were published in Apžvalga. That love was true, because the Catholic faith and the strive to salvation was at the top of that system of values.

${ }^{36}$ Ibid., p. 19.

${ }^{37}$ Bangputys [Antanas Baranauskas ?], 'Bažnytinè unija Lietuvoje', Apžvalga, nr. 8 (1890), pp. 58-61.

${ }^{38}$ Ibid. p. 60.

${ }^{39}$ Mikšytè, Baranauskas, p. 233-234.

${ }^{40}$ D. Skroblus [Petras Viengalis], 'Tikra tèvynès meilè', Apžvalga, nr. 1 (1890), p. 3-4.

${ }^{41}$ Tumas, 'Apžvalga', p. 17.

${ }^{42}$ Ibid., p. 8.

${ }^{43}$ Ibid., p. 3.

${ }^{44}$ Reminiscences of Juozas Skvireckas about the Theological Seminary of Kaunas. The Kaunas Archdiocesan Chapter Archive, b. 291, 1. 2. 
The gentry mentality of Barauskas is manifested in his conception of the nation: it consists of two groups - the 'gentry' and the 'common people'. ${ }^{45}$ The two groups have their own roles: the former is 'indispensable to the people for its education' and as an example, and the latter 'perform various temporary tasks, which are necessary for the salvation of the soul' ${ }^{46}$ and therefore they should be carried out. The attitude of that type is a synthesis (devised by a clergyman of the gentry mentality) of the Catholic Church's teaching about the nation and society (acknowledging the existence of estates in it). Nevertheless, certain traces of the metamorphosis of that attitude in the direction of a modern loyalty to the nation could be detected in Apžvalga.

Father Kazimieras Pakalniškis (b. in 1866) reiterated a similar idea about the composition of a nation as consisting of two parts - the gentry and the peasants. According to him, the concord of the two parts is a condition of the nation's (or Lithuanianness) development, ${ }^{47}$ and the latter is the goal. On the other hand, the unity of the two parts curbs the influence of Orthodoxy. Therefore, although Pakalniškis acknowledged the Polonization of the gentry, Apžvalga, 'for the time being', refused to be in opposition to the Poles. ${ }^{48}$ 'For the time being' meant temporarily, the more so that Pakalniškis (for the first time in the Apžvalga) had already expressed a negative, though rather mild, opinion about the Lithuanians using the Polish language. ${ }^{49}$ Since then, the further the more often, the attitude to Lithuanian and its usage became a sort of standard in the evaluation of a clergyman and a representative of the gentry. The ethnolinguistic perception of the nation, peculiar to modern nationalism, was constantly gaining ground in contrast to the traditional gentry outlook.

The notion of the two-part nation was repeated by Pakalniškis, the editor of the newspaper, in $1892,{ }^{50}$ the accents, however, being different. The attitude to the national movement became the criterion in the assessment of all the estates, and 'Catholicism and Lithuanianness' 51 had to be the basis of their concord, unity and mutual love. Mean-

${ }^{45}$ Skroblus, 'Tèvynès meilè', p. 4.

${ }^{46}$ Ibid, p. 4.

${ }^{47}$ P. Zuikis [Pakalniškis], 'Isz szalies žiurint', Apžvalga, nr. 17 (1890), p. 133.

${ }^{48}$ Ibid.

${ }^{49}$ Jurgis Szermunelis [Pakalniškis], 'Keletas žodžių del atskalunu', Apžvalga, nr. 16 (1890), p. 121.

so J. Szermunelis [Pakalniškis], 'Sziz - tas apie mūsų bajoriją kunigiją ir “mužikiją"' Apžvalga, nr. 6 (1892), pp. 42-44.

${ }^{51}$ Ibid. p. 44. 
while the pro-Polish political ideals - 'dreams' about 'Jeszcze Polska nie zginęůa' (Poland has not yet perished) identified with the gentry and a part of the estate owners, were rejected entirely. ${ }^{52}$ In the article that rejection of the old political ideals and the declaration of national activity was designated as a tension between 'Polonomaniacs' and 'Litvomaniacs.' It could also be attributed to the conflict between the generations. True, the 'Polonomaniacs' were not directly named 'the old', while the 'Litvomaniac' priests associated their origin and ideals with the abolition of serfdom - a new (or young) phenomenon and the ensuing changes in the social composition of the clergy in favour of the peasantry. ${ }^{53}$ Thus the social roots conditioned the attitudes and the trends of the activities of the clergy.

In that way Apžvalga gradually moved away from the ideology of the Seminary's professors. That process displayed the beginnings of the conflict between the generations on the basis of Polishness vs Lithuanianness. In 1894 the situation in the theological seminaries was criticized for their pro-Polish orientation and the infringement of the rights of the Lithuanian language in them. ${ }^{54}$ The position of Apžvalga with respect to nationalism and Catholicism and their relationship to Polishness was not static, it continually underwent changes. At first its editors endeavoured to preserve the balance between the ideas of Lithuanianness and Polishness and to reach a modus vivendi. In the first year of its publication the ideological conflict did not exist - the viewpoint of the older generation was accepted and tolerated. When in 1890 Vienybe, a Lithuanian newspaper published in the USA, reproached the Apžvalga for its Polish bias, Father Pranas Urbonavičius (by the way, a gentry representative ${ }^{55}$ ) (b. in 1868) retorted: 'We can love our dear homeland and language' and not be enemies of the Poles. ${ }^{56}$

However, the tension between the clergymen of Lithuanian and Polish orientation was inevitable when Apžvalga, edited by Pakalniškis, widened the sphere of the use of Lithuanian, directly associating Catholicism with Lithuanianism. Correspondingly, that meant generational conflict. The orientation of the Polish gentry and clergy

${ }^{52}$ Ibid., pp. 43-44.

${ }^{53}$ Ibid., p. 43.

${ }^{54}$ Burbulys [?], 'Isz Szalies žiurint', Apžvalga, nr. 18 (1894), p. 137-139.

${ }_{55}$ The 1886 list of the seminarians of the Telšiai Roman Catholic Seminary, Lietuvos valstybės istorijos archyvas (henceforth LVIA), f. 378, BS 1877 m., b. 379, 1. 433 .

${ }^{56}$ Pr. Vytautas [P. Urbonavičius], 'Isz szalies žiurint', Apžvalga, nr. 10 (1890), p. 76. 
was identified with the 'old dreams' and 'old patriotism', 57 and 'Litvomania' with the ideals of the young clergy. ${ }^{58}$ The scale of the conflict was checked by the fact that in view Apžvalga's, enemy number one was the Russification threat to the Catholic Church (both Lithuanian and Polish), and enemy number two was the liberal lay intellectuals, whose positive contribution to the Lithuanian national movement was not recognized by the newspaper.

The appearance of a new Catholic clerical newspaper - Tévynés Sargas (Homeland Guardian) (henceforth Sargas) in 1896 was caused by the dissatisfaction with the tone and attitudes of Apžvalga on the part of one group of (mostly Juozas Tumas, Pranas Būčys (b. 1872), Andrius Dubinskas (b.1868) (the latter two had studied at the Seinai Seminary). ${ }^{59}$ Sargas was more lenient with the laity, at least in its declarations. Tumas was the life and soul of the Sargas. Already in 1894 in his dispute with the rector of Mitau (Jelgava) Petras Valentas (b. 1861) Tumas argued that the Catholic Church had to maintain the individuality and nationality of the people and thus gain the devotion of the believers. ${ }^{60}$. Tumas wrote: 'If religion required me to give up my inborn nationality, I would relinquish 'such' religion. ... However, true Catholicism would never require that from me'. ${ }^{61}$ Thus preferring nationality, Tumas believed in 'true' Catholicism, which would not confront one with the dilemma of 'either or'. Tumas asserted the synthesis of the 'inborn' nationality and Catholicism. Besides, nationalism for Tumas was a condition of profound faith. According to him, 'the love for God, devotion to the Church never ousts the love of the family and still less the love for the homeland from the human heart' ${ }^{62}$ In Sargas Tumas was less radical, in particular with respect to the individual's self-determination concerning nationality and religion, though both those aspects remained crucial and inseparable for those adhering to the attitudes of the newspaper. Such an exceptional treatment of nationalism was conditioned by the ideals raised by the

${ }^{57}$ A. J. [Aleksandras Dambrauskas], 'Padek Dieve', ibid., nr. 1 (1894), p. 5; Užrubežinis [?], Isz svetur', ibid. nr. 2 (1894), p. 16.

${ }^{58}$ [?], '"Pro domo sua". Atsakymas kunigui ne-litvomanui', ibid., nr. 14 (1894), pp. 105-108.

59 Tumas to Sofija [Kymantaitė-Čiurlionienè], letter of 11 March 1911. Vilniaus universiteto bibliotekos Rankraščiu skyrius (henceforth VUB RS), f. 1, b. F. $58,1.151$.

${ }^{60}$ Merkelis, Vaižgantas, p. 52.

${ }^{61}$ Ibid.

${ }^{62}$ Apie lietuviu raštiją ir švietimą [undated, about the turn of the century],

VUB RS, f. 1, b. F569, 1. 49, 62. 
laity and fostered both by the liberal Varpas and the Social Democratic section of society. The clergymen of Sargas had one more example the Polish ultramontanism identifying Catholicism and nationalism. For the ultramontanists religion had become the aim of the rebirth of Poland rather than its means. ${ }^{63}$ Ultramontanism, though familiar to Sargas, had not fully pervaded it, and that was also attested by its attitude to the laity. The first motto of Sargas was an accurate quotation from the letter of Adam Czartoryski of 15 March 1844 to Father Aleksander Jełowicki, which is found in the study on Polish ultramontanism. ${ }^{64}$ The old clergy, acknowledging the cultural synthesis of Catholicism and Polishness, possibly were closer to ultramontanism. The declaration of the synthesis of Catholicism and Lithuanianness in Sargas led to inevitable Lithuanian-Polish tensions. Sometimes the arguments used by the newspaper were very similar to those found in the illegal lay publications. Sargas asserted that the fact that Lithuanians and Poles were Catholics did not presuppose their common cultural and political fate. ${ }^{65}$ It is noteworthy that Sargas did not reject the chance of the political emancipation from Russian rule, and with this aim in view "the Lithuanians are willing and ready to act together with the Poles, but only as equal and free, and that the Poles should forget the old traditions and not tease Lithuanians with outmoded treatises and unions'. ${ }^{66}$ Thus, contributors to Sargas rejected the union tradition, describing it as 'old', and respectively considered themselves as 'young' or 'new' Lithuania. That kind of approach and the epithet 'young' were typical of many European national movements.

Sargas presented interesting statistics of the distribution of the Žemaitijan diocese priests according to their age. It asserted that the priests up to forty years of age were notable (their total number was $315)$, because their way of thinking was different. ${ }^{67}$ The 182 clergymen, the age of which was between forty and sixty years, occupied an intermediate position, while the rest -145 persons - belonged to the old times and understood only the past. ${ }^{68}$ The logic of the classification leads to the idea that age and viewpoints were interdependent, to put it

${ }^{63}$ Rett Ludwikowski, 'Ultramontanism a konserwatizm polski XIX w.', Zeszyty naukowe uniwersitetu Jagiellońskiego. Prace z nauk politycznych, z. 11 (1978), s. 110.

${ }^{64}$ Pawel Smolikowski, Historia Zgromadzenia Zmartwychwstania Pańskiego, t. 3 (Kraków, 189[6?]), s. 91-92; cited from Ludwikowski, Ultramontanism, s. 112.

${ }^{65}$ Vaižgantas [Juozas Tumas], 'Russko-Polskie otnosheniia, ocherk napisal graf Leliwa, Leiptsig, 1895’, Sargas, nr. 1, (1896), p. 28.

${ }^{66}$ Paryžietis [?], 'Suvažiavimas', Ibid. nr. 10-11 (1900), p. 84-85.

${ }^{67}$ [?], 'Truputis skaitlių isz Žemaiczių Vyskupijos', Sargas, nr. 1 (1900), p. 66. ${ }^{68}$ Ibid. 
differently, the generation gap was expressed in terms of age and attitudes. The distinction of age groups again showed the social content of the generation gap (already observed in Apžvalga): clergymen born after the abolition of serfdom, i.e., not older than forty years, made up a separate distinct group. However, this division was not rigid. The adherents of Sargas belonged to the most numerous section - of those up to forty years. The number of the active contributors to the publication was only about fifty - a sixth of the that 'big' generation. The others were either passive or belonged to those of the old generation. The above-mentioned rector of Mitau, Valentas, with whom Tumas disagreed on nationalism, could be attributed to the younger generation only on the basis of his age rather than his viewpoints. The age analysis of the contributors to Apžvalga and Sargas showed that the majority of them were born between 1860 and 1875 (70 per cent in Apžvalga and 80 per cent in Sargas). However, the percentage of those born before 1860 was about 32 in Apžvalga and about 8 in Sargas. That in part accounted for the more liberal position of Apžvalga towards Polishness in the first years of its publication. The attitudes of the editors Pakalniškis and Tumas, as well as the changing sociocultural and political context, were also instrumental in forming the policy of the newspapers. In Apžvalga generational conflict was understood in its narrow sense - the date of birth and the use of Lithuanian were the criteria of identification. For Sargas the self-determination of the clergyman himself was also significant. However, the greatest differences between the two newspapers were not in the interpretation of the interdependency of nationalism and Catholicism, but in the treatment of the laity. Apžvalga adhered to the so-called old attitude considering liberalism and socialism as its own (and society's) greatest enemies - a position typical of the nineteenth-century Catholic Church. Sargas was more modern and inclined to co-operation and compromise with lay intellectuals even acknowledging that 'all of us are pure democrats by origin and frame of mind; at the same time we are also liberals to a small extent, only some are more oriented towards Socialism, while others towards Catholicism' ${ }^{69}$ In a wider context of the teaching of the Catholic Church the latter approach was closer to the new methods of the social doctrine of the Church in the late nineteenth century.

In 1900 the editorial board of the Sargas started publishing one more newspaper - Žinyčia (Knowledge). It was the intent of Tumas to have a free hand and reflect the interests of the intellectuals. ${ }^{70}$ The

${ }^{69}$ Vais. [Tumas], 'Garbus Lietuviai', Žinyčia, nr. 1 (1900), p. 5.

${ }^{70}$ Ibid., p. 2. 
new newspaper was the first Lithuanian clerical publication intended both for the clergy and the laity. The overwhelming majority of its contributors belonged to the 1860-75 generation, they also wrote for Sargas and some of them for Apžvalga as well. The engagement of Žinycia to the Church was more moderate, since its lay readership had to be taken into account. However, there was no moderateness in the polemics among the confrères themselves. Their discussion in the newspaper on the relationship between nationalism and Catholicism acquired a form of two 'manias' - 'Litvomania' and 'Polonomania'. For the 'Litvomaniacs' the combination of Catholicism and nationalism was clear and unquestionable. In this respect they only repeated their viewpoint established already in Apžvalga and Sargas. In Žinyčia, however, the old generation - the 'Polonomaniacs' - also expressed their opposite attitude to the same questions. Their arguments showed that their attitudes were based not on political ideals - the essence of the conflict was their unwillingness to admit the right of Lithuanian (first of all, in the Church) - for them 'their own (emphasized by Sargas) language is Polish and Žemaitijan'. ${ }^{71}$ On the other hand, did that not demonstrate the unflagging existence of the two-level national gentry consciousness of gente Lituanus natione Polonus? That also proved their allegiance to 'the drama of their youth' - the Uprising of 1863, which defended such attitudes. However, at the turn of the century that caused the tension between the generations fostering different ideals. ${ }^{72}$ For the young, perceiving nationalism in the ethnolinguistic terms only Lithuanian was their language, while the Uprising was the matter of the 'Polonomaniacs', 'a stupid revolt'. ${ }^{73}$ Those polemics revealed not only the different interpretation of nationalism. The generations were also divided by different perceptions of the duties of the clergy. The activities of the older clergymen had to confine themselves to ensuring the concord in society. ${ }^{74}$ The clergyman had only to preserve Catholicism as it had been before the tsarist repression and consider Orthodoxy as its principal enemy. Such posture often bordered on utter passiveness and indifference to any activity. By the way, the criticisms in Sargas showed that similar flaws were typical not only of the older generation, but of the 'silent' majority of the clergy in general. Tumas wrote: 'It is God's curse or what else - as

${ }^{71}$ Red. [J. Tumas], 'Protestai pries “litvomanus”', Žinyčia, nr. 4-5 (1902), p. 115.

${ }^{72}$ Mannheim, Essays, p. 301.

${ }^{73}$ A. J. [A. Dambrauskas], 'Koks tai paukštis “kun” V. Dembskis?', Sargas, nr. 4-5 (1902), pp. 3, 6.

${ }^{74}$ Red. [J. Tumas], 'Protestai prieš “litvomanus””, Žinyčia, nr. 4-5 (1902), p. 116. 
soon as you are dealing with a priest, you meet with narrow-mindedness, indifference to the problems of society and unwillingness to lift a finger and do more than is elementarily required by the parish. True, sometimes a finger is raised, but only to point at an agitator rather than at the idea as such'. ${ }^{75}$ Thus, criticism expanded the ideology of the generation.

The young combined their pastoral mission with nationalism and participation in the Lithuanian national movement, rejecting the idea that a Lithuanian patriot could not be a good priest and that Lithuanian activity contradicted the priestly vocation. ${ }^{76}$ The criticism of social passiveness in Žinyčia was a consistent element of the stance of the young 'Litvomaniacs' rather than mere rhetoric.

Thus, Žinyčia exposed the basis of the ideological differentiantion among the clergy. It also expanded the content of the generation gap: recognizing the age and social criteria in the identification of the generation it accepted them not as the ultimate standards in establishing the stance of the clergyman. One more important factor was the self-determination of the person himself. In the consideration of Žinyčia, and in a somewhat wider sense in Sargas as well, any clergyman irrespective of his age was considered 'old' if did not see the perspective of modern Lithuania. The self-determination was of particular importance for the young clergymen. The evaluation of one's stance was a feature of the individual, characterized by the categories of modern, free (or getting free from the estate) thinking. Thus, the contrast of young vs. old in the clergy of Lithuania in the late nineteenth century was conditioned by different interpretations of the combination of nationalism and Catholicism, which in its turn depended on:

1) the attempts of a part of the clergy to combine their engagement to the Church with Lithuanian modern nationalism, which determined the synthesis of Catholicism and nationalism (Lithuanianness) in their views. That type of attitude to the Lithuanian national movement expanded the conception of the pastoral duties as well - an active attitude of the clergyman to the socio-cultural context was declared, and social passiveness was denounced.

2) the other part of the clergy remained faithful to the (political or cultural) idea of the Lithuanian-Polish union and in their attitudes placed emphasis on Catholicism - those two aspects formed their unifying factor.

${ }^{75}$ Tumas to Dambrauskas, letter of 25 Oct. 1904, VUB RS, f.1, E. 118, letter 51 (pages unnumbered).

${ }^{76}$ Adomas Jakštas [Dambrauskas], 'Kunigas - Lietuvys', Žinyčia, nr. 1 (1900), p. 114. 
In summing up, it can be said that these differences in opinions displayed themselves rather as the differences of cultural and political orientations than generational conflict in the sense of formal, biological chronology. The contrast of the young vs the old manifested itself not so much in the age group conflict, as in the different interpretations of the relationship between Catholicism and nationalism and different models of activity among the members of the same age group.

\section{Author Details}

Vilma Žaltauskaite is a doctoral student at the Lithuanian Institute of History, Vilnius, researching the policy and attitudes of the Lithuanian Catholic clergy in the context of the political and sociocultural changes in the country in the late nineteenth and early twentieth centuries.

Address: Department of 19th-Century History, Lithuanian Institute of History, Kražiu 5, LT-2001 Vilnius, Lithuania

Email: zaltys@takas.lt

\section{KATALIKYBE் IR TAUTIŠKUMAS JAUNOSIOS LIETUVIU DVASININKŲ KARTOS PAŽIŪROSE XIX A. PAB. - XX A. PR.}

Santrauka

\section{VILMA ŽALTAUSKAITÉ}

Straipsnyje analizuojama katalikų dvasininkijos laikysena modernaus lietuviškojo nacionalizmo raiškos kontekste. XIX a. pab. dvasininkų nuostatos istoriografijoje dažnai ivardijamos senosios ir jaunosios dvasininku kartu konfliktu. Todèl siekiama išsiaiškinti, kuo pragristas toks skirstymas, kiek konfliktas buvo sąlygotas amžiaus skirtumų, o kiek pažiūru susidūrimo - skirtingos tautiškumo ir katališkumo dermès sampratos. Katalikiškos pakraipos tekstu analizė leidžia teigti, kad idejinę diferencijaciją dvasininkijoje kartų konfliktu galima vadinti tik iš dalies. Senujų - jaunujų priešpriešą sąlygojo ne amžiaus grupių konfliktas, bet suponuotas ir skirtingai suvokiamas dvasininko pareigos bei katalikybẻs ir tautiškumo santykis. Itampa minètu pagrindu reiškèsi ir vienos amžiaus grupès dvasininkų tarpe. Pozityviai vertinantys lietuvių tautini judejjimą ir jame dalyvaujantys dvasininkai deklaravo katalikybès ir tautiškumo (lietuviškumo) sintezę, tuo tarpu kita dvasininkijos dalis savo nuostatose pirmiausia akcentavo katalikybę - universalią dimensiją, o moderniam lietuviškam nacionalizmui priešpriešino Lietuvos ir Lenkijos kultūrinès-politinès unijos idèją. 